\title{
講演 6
}

\section{非小細胞肺癌の治療一Update一}

\section{大熊裕介 ${ }^{1}$}

\section{1.はじめに}

Precision Medicine と免疫チェックポイント阻害剤 (ICI)の登場により, 非小細胞肺癌の薬物療法は治療シー クエンスやモダリティーの組み合わせが多様となり，診 療フローはより細分化され，複雑になってきた，肺癌診 療ガイドラインも 1 年先の承認を踏まえて現場との乘離 が少なくなるよう配慮しているものの（図 1), 治療フ レームの変動が速いスピードで展開されており, ユー ザーフレンドリーとなり難い.

本セッションでは本邦では未承認のエビデンスも含む が， 2018 年に承認もしくは適応拡大されたもの，また, 2019 年に向けて治療の枠組みが変わるようなエビデン スを紹介する。

\section{2. 周術期および局所進行期の薬物療法}

周術期薬物療法では EGFR 遺伝子変異陽性非小細胞 肺癌に対し, 術後補助化学療法として EGFR 阻害剂の効 果を検証する ADJUVANT 試験 ${ }^{1}$ が実施された。主要評 価項目の無病生存期間で優越性を検証した（ハザード比 [HR] 0.60, 95\% confidence interval [CI] 0.42 0.87) \& のの, 承認要件, 間質性肺疾患のリスク, コントロール 群の治療成績が不良であり，結果を外挿することができ ない.

また, ニボルマブ (nivo) による術前補助化学療法の探 索的試験 2 では, 少数の検討であったが奏効割合が $10 \%$, 病勢進行が $5 \%$, 病理学的奏効が $45 \%$ と有望な結果で あった。 今後，周術期においても ICI の効果が期待され る.

局所進行期では，PACIFIC 試験 3 において III 期非小 細胞肺癌に対し，化学放射線療法後，最終照射日から 6 週間以内に 1 年間デュルバルマブを投与する試験治療群 がプラセボ群に対し，無増悪生存期間 (PFS) で優越性を
示した（HR 0.52，95\%CI 0.42〜0.65）。この結果を受け, 切除不能局所進行非小細胞肺癌に対する化学放射線療法 後の地固め療法として, デュルバルマブが 2018 年 7 月に 本邦で承認された。 その後、全生存期間（OS）の結果も 発表され、同様にデュラバルマブ群で優越性を示した (HR 0.68, 99.73\%CI 0.47〜0.997).

\section{3. 進行非小細胞肺癌に対する薬物療法}

\section{1. $\mathrm{ICI}$}

(1)プラチナ併用療法に対するぺムブロリズマブの効果の 検証

PD-L1 発現 (TPS) $\geq 1 \%$ の未治療 PD-L1 陽性進行非小 細胞肺癌を対象にペムブロリズマブ（pembro）とプラチ ナ併用療法を比較した KEYNOTE042 試験が行われ, pembro 群で OSの優越性を示した（HR 0.81，95\%CI 0.71 0.93).この試験では KEYNOTE024 試験に参加し なかった地域・施設を対象とし, 再現性を示すことが期 待された。 TPS $\geq 50 \%, T P S \geq 20 \%, T P S \geq 1 \%$ いずれの サブグループでも pembro 群で良好な傾向がみられた が，いずれも 3 カ月まではプラチナ併用療法群を Kaplan-Meier 曲線で下回っていた。 また，プラチナ併用 群では pembro のクロスオーバーが許容されていなかっ た点で解釈に注意が必要である.

(2)アテゾリズマブの承認

プラチナ併用療法既治療例に対し，OAK 試験の結果 を基に PD-L1 阻害剤であるアテゾリズマブ (atezo) が承 認された。この試験では, atezo はドセタキセルに対し, OS で良好な結果を示し (HR 0.73，95\%CI 0.6〜0.89)，サ ブグループでも組織型に関わらず atezo 群で良好であっ た。 


\section{非小細胞肺癌 : N 期(サブブループの同定)}

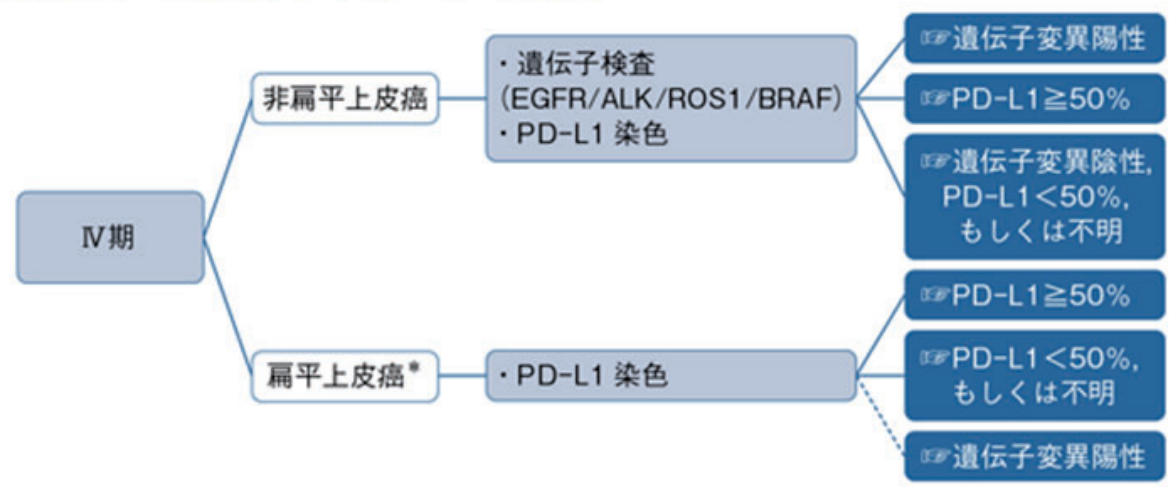

\section{*「転移など各病態に対する治癔」も参照

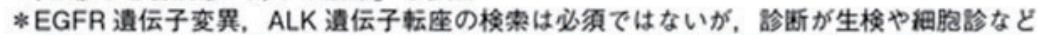 の微量の検体の場合においては，腺㴔が合まれない組織でもEGFR 遺伝子変異，ALK 遺 伝子転座などの梌索を考慮する。}

図 1. IV 期非小細胞肺癌の化学療法（EBM の手法による肺癌診療ガイドライン 2017 年版より).

\subsection{ICI による併用療法}

(1)進行扁平上皮肺癌に対するプラチナ併用 $+\mathrm{ICI}$ 併用療 法

未治療進行扁平上皮肺癌を対象にパクリタキセル (PTX) もしくはアルブミン懸濁型 (nab)-PTX/カルボプ ラチン $(\mathrm{CBDCA})$ (プラチナ併用) に pembro の上乗せの 意義を検証するため KEYNOTE407 試験が実施された. OS では pembro +プラチナ併用群がプラチナ併用群に 対して優越性を示し，PD-L1 発現が低，中，高のいずれ のサブグループでも再現性がみられた。 これに対し，

PTX もしくは nab-PTX/CBDCA にatezoの上乗せ効果 を検証する IMpower131 試験では中間解析では atezo 併 用療法で PFS は改善していたものの, OS では改善を示 さなかった.

(2)非扁平上皮肺癌に対するプラチナ併用 $+\mathrm{ICI}$ 併用療法

未治療非扁平非小細胞肺癌を対象とし，プラチナ併用 療法に atezo 併用の有用性を検討する IMpower150 試 験4では，EGFR 遺伝子変異/ALK 融合遺伝子を除いた ITT-WT と EGFR 遺伝子変異/ALK 融合遺伝子を対象 としたITT-MTを対象に実施された. ITT-WT, ITTMT いずれのコホートでもプラチナ併用療法+ベバシズ マブ+ atezo 群 (4 剂併用群) が，プラチナ併用療法+ベ バシズマブ群（3 剂併用群）に対して有用性を示した. PFS では, ITT-WT では 4 剂併用群が 3 剂併用療法より も優越性を示し（HR 0.62，95\% CI 0.52〜0.74）， EGFR 遺伝子変異陽性例でも 4 剂併用療法で良好であった $(\mathrm{HR}$ 0.59, 95\% CI，0.37〜0.94). 少数の解析のため注意が必要 であるものの, ドライバー変異のサブグループ解析でも 4 剤併用群が良好な傾向がみられたことと，ドライバー
変異陽性例は無効例が多いことからこの対象には化学療 法と ICI の併用療法が期待される.

一方, ペメトレキセド+プラチナ併用療法では, 既に ランダム化第 II 相試験である KEYNOTE021 試験（cohort G)の結果から米国では承認されている。これを検証 するため, 未治療進行非扁平上皮性非小細胞肺癌に対し, ペメトレキセド+プラチナ併用療法に pembro の上乗せ を検証する KEYNOTE189 試験 5 が実施された。この試 験ではドライバー遺伝子異常が除かれていた．PFSは 3 剂併用群で 8.8 力月に対し, プラチナ併用療法では 4.9 カ 月と 3 剂併用療法で良好であった（HR 0.52，95\% CI， 0.43 0.64). この試験では, アジア人は少数しか参加して いなかった.

\section{(3) ICI 併用療法}

CheckMate227 試験6 のサブコホートにおいて, 腫瘍変 異負荷 $(\mathrm{TMB}) \geq 10 \mathrm{mut} / \mathrm{MB}$ を有する未治療非小細胞肺 癌患者では，化学療法群では 1 年無増生存割合が $13.2 \%$ であったのに対し，nivo+イピリムマブ (ipi) 併用療法群 では $42.6 \%$ と有望な効果を示した（HR 0.58, $97.5 \% \mathrm{CI}$ 0.41 0.81), OS は ICI 併用療法群で 14.4 力月, 化学療法 群で 13.2 カ 月であり，忍容性もあると考えられ，米国で 承認されたＩCIがマルチプレックス遺伝子パネル検査 により効果予測されたことが重要と考えられた.

\section{3. ドライバー遺伝子異常に対する薬物療法} (1)EGFR 遺伝子変異

A. dacomitinib

脳転移を除く, EGFR 遺伝子陽性未治療進行非小細胞 肺癌を対象とした ARCHER1050 試験の最終解析では主 要評価項目であるPFS に続き, OSでも dacomitinib が 
ゲフィチニブに対して優越性を示した（HR 0.76, 95\% CI 0.58〜0.99). 7 しかし, 脳転移例が除外された点, 毒性 と生存ベネフィット,オシメルチニブの適応拡大もあり, 強い推奨には至らない.

\section{B. オシメルチニブの適応拡大}

FLAURA 試験8において, オシメルチニブがゲフィチ ニブに対して PFS において優越性を検証(HR 0.46, 95\% CI， 0.37〜0.57） し，この結果を受け，米国では 2018 年 4 月に, 本邦では 8 月に未治療 EGFR 遺伝子陽性進行非 小細胞肺癌に対して適応拡大となった. 今後, OS の結果 が待たれるが, 第 2 世代 EGFR 阻害剤を初回治療として 開始した場合の治療シークエンスと比ベ, どちらが最適 か結論は出ていない.

C. アファチニブの新たな標的

L861Q, G719Q, S768X や S768I といった uncommon EGFR 遺伝子陽性非小細胞肺癌に対し, LuxLung 試験シ リーズの統合解析の結果, アファチニブが米国で追加承 認された. 同一対象について, オシメルチニブの効果は 少数例で報告されている.また, EGFR 阻害剤が奏効しな い exon 20 挿入に対しては poziotinib などの新規薬剤が 早期試験の結果では期待されている. 9

D. EGFR 阻害剂の最適なパートナーは?

\section{a. NEJ009 試験}

REAL2000 およびNEJ002 試験では, EGFR 遺伝子変 異陽性進行非小細胞肺癌に対し, ゲフィチニブで初回治 療を受けた患者の 35\%〜 50\% 以上がプラチナ併用療法 を受けていなかった。このため, 初回治療より EGFR 阻害剂にプラチナ併用療法を併用する戦略を検証するた め, NEJ009 試験が実施された. 中間解析においてゲフィ チニブ/カルボプラチン/ペメトレキセド併用療法 (GCP 群) の OS が 52.2 カ月, ゲフィチニブ群の OS が 38.8 ケ 月であった (HR 0.69, p=0.013). PFS2 では GCP 群の優 越性を示すことができず, また, OS は探索的な結果のた め解釈に注意する。

\section{b. JO25567 試験/NEJ026 試験}

JO25567 試験はエルロチニブ (E) 群とエルロチニブ+ ベバシズマブ (EB) 群を探索的に比較したランダム化第 II 相試験である. 主要評価項目である PFS は既に発表さ れており, 同意を得られた患者でのみ事後解析を行った. OS は EB 群で 47.0 カ月, E 群で 47.4 カ月と差がみられ なかった（HR 0.81，95\%CI， 0.53〜 1.23）. その後, 検証 的試験としてNEJ026 試験が行われ, 中間解析において $\mathrm{PFS}$ では EB 群が $\mathrm{E}$ 群に対し, 有用性を示した（HR= 0.56, 95\%CI 0.39〜0.80).

\section{(2)ALK 融合遺伝子}

A. ロルラチニブ

ALK 融合遺伝子陽性非小細胞肺癌に対し, 第 3 世代
ALK 阻害剤であるロルラチニブがALK 阻害剤未治療 例では奏効割合 90\%, 既治療例においては 30〜 70\% と高 い奏効割合を示した.

\section{B. ALEX 試験}

現在, 本邦では ALK 融合遺伝子陽性非小細胞肺癌に 対して, クリゾチニブ, アレクチニブ, セリチニブが承 認されている（ロルラチニブは 2018 年 9 月に承認). ク リゾチニブとアレクチニブを比較したJ-ALEX 試験で は, アレクチニブが効果・毒性ともに有用性を示した (HR 0.23, 99.7\%CI 0.17〜0.81). 日本以外の地域で実施さ れた ALEX 試験でも同様に優越性を再現した（HR 0.47, 95\% CI 0.34〜0.65). 10 この結果, アレクチニブが ALK 融合遺伝子陽性進行非小細胞肺癌の初回化学療法の標準 治療として認識された。

アレクチニブ耐性後の ALK 阻害剂については, ASCEND9 試験の結果より奏効割合が 25\% と一定の有効性 を示した. Brigatinib は米国では既に承認されているが、 本邦では治験が行われている. 第 II 相試験である ALTA 試験の結果では、クリゾチニブ既治療例に対して奏効割 合は 56\%、PFS は 16.7 カ月であった.

\section{(3) BRAF 遺伝子変異}

BRAF (v-Raf murine sarcoma viral oncogene homolog B）は $\mathrm{MEK} / \mathrm{ERK}$ シグナル伝達経路の一部を構成するセ リン/スレオニンキナーゼとして知られ, 肺腺癌では 1 $2 \%$ と希少であり, 契煙者でもみられる. 既治療 BRAF 遺伝子変異陽性例での第 II 相試験では, 奏効割合が 63\%, PFSは 9.7 カと良好な結果であった.

\section{2019 年に向けて}

今後, 肺がん薬物療法の治療選択のため, マルチプレッ クス遺伝子パネル検査が実装される. クリニカルシーク エンスは希少肺癌の遺伝子サブタイプの診断にとどまら ず, TMB による ICI の選択につながる可能性もある. 現 状, ICI は 22C3 PD-L1 IHC の枠組みに依拠しているが, TMB に依拠した治療戦略やプラチナ併用療法+免疫併 用療法により, PD-L1 のステータスに関わらず治療選択 ができるようになるだろう。この際, TMB も PD-L1 同 様, どのアッセイ系で測定するかが問題となる. また, 血漿検体による診断などより侵襲性の低い検査での開発 が期待される.

ゲノムデータや臨床データが膨大となり, IT による支 援も期待されている. さらに, これらデータを統合し, データマイニングを行っていくことで新たな知識を発見 できる可能性がある。このため, Syapse 社 (https:// www.syapse.com/）が提供しているような, マルチプ レックス遺伝子パネル検査や電子カルテに蓄積された臨 床データを統合し, 診療の支援・ビッグデータを活用す 
るような IT プラットフォームを整備することも今後は

課題の一つとなるだろう.

本論文内容に関連する著者の利益相反 : 大熊裕介〔委受託研

究 (治験等)] 中外製薬 (株), 武田薬品工業 (株)

\section{REFERENCES}

1. Zhong WZ, Wang Q, Mao WM, Xu ST, Wu L, Shen Y, et al. Gefitinib versus vinorelbine plus cisplatin as adjuvant treatment for stage II-IIIA ( N 1-N 2 ) EGFR-mutant NSCLC (ADJUVANT / CTONG 1104): a randomised, open-label, phase 3 study. Lancet Oncol. 2018;19:139-148.

2. Forde PM, Chaft JE, Smith KN, Anagnostou V, Cottrell TR, Hellmann MD, et al. Neoadjuvant PD-1 Blockade in Resectable Lung Cancer. N Engl J Med. 2018;378:19761986.

3. Antonia SJ, Villegas A, Daniel D, Vicente D, Murakami $\mathrm{S}$, Hui R, et al. Durvalumab after Chemoradiotherapy in Stage III Non-Small-Cell Lung Cancer. N Engl J Med. 2017; 377:1919-1929.

4. Socinski MA, Jotte RM, Cappuzzo F, Orlandi F, Stroyakovskiy D, Nogami N, et al. Atezolizumab for First-Line Treatment of Metastatic Nonsquamous NSCLC. N Engl J Med. 2018;378:2288-2301.

5. Gandhi L, Rodriguez-Abreu D, Gadgeel S, Esteban E,
Felip E, De Angelis F, et al. Pembrolizumab plus Chemotherapy in Metastatic Non-Small-Cell Lung Cancer. $N$ Engl J Med. 2018;378:2078-2092.

6. Hellmann MD, Ciuleanu TE, Pluzanski A, Lee JS, Otterson GA, Audigier-Valette C, et al. Nivolumab plus Ipilimumab in Lung Cancer with a High Tumor Mutational Burden. N Engl J Med. 2018;378:2093-2104.

7. Mok TS, Cheng Y, Zhou X, Lee KH, Nakagawa K, Niho $\mathrm{S}$, et al. Improvement in Overall Survival in a Randomized Study That Compared Dacomitinib With Gefitinib in Patients With Advanced Non-Small-Cell Lung Cancer and EGFR-Activating Mutations. J Clin Oncol. 2018;36: 2244-2250.

8. Soria JC, Ohe Y, Vansteenkiste J, Reungwetwattana T, Chewaskulyong B, Lee $\mathrm{KH}$, et al. Osimertinib in Untreated EGFR-Mutated Advanced Non-Small-Cell Lung Cancer. N Engl J Med. 2018;378:113-125.

9. Robichaux JP, Elamin YY, Tan Z, Carter BW, Zhang S, Liu S, et al. Mechanisms and clinical activity of an EGFR and HER2 exon 20-selective kinase inhibitor in non-small cell lung cancer. Nat Med. 2018;24:638-646.

10. Peters S, Camidge DR, Shaw AT, Gadgeel S, Ahn JS, Kim DW, et al. Alectinib versus Crizotinib in Untreated ALK-Positive Non-Small-Cell Lung Cancer. $N$ Engl J Med. 2017;377:829-838. 